\title{
An Unusual Case of Orf with Erythema Multiforme and Vesiculo- bullous Lesions after Eid al-Adha
}

\author{
Kurban Bayramı Sonrası, Eritema Multiforme ve Vezikülobüllöz Lezyonlarla Seyreden \\ Sıradışı Bir Orf Olgusu
}

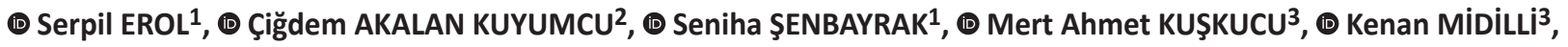 \\ (D) Sema AYTEKIN ${ }^{4}$, (D) Pembegül GÜNEŞ ${ }^{5}$ \\ 1 University of Health Sciences, Haydarpaşa Numune Training and Research Hospital, Clinic of Infectious Diseases and Clinical Microbiology, \\ istanbul, Turkey \\ 2University of Health Sciences, Sancaktepe Şehit Prof. Dr. Ilhan Varank Training and Research Hospital, Clinic of Infectious Diseases and Clinical \\ Microbiology, İstanbul, Turkey \\ 3istanbul University Cerrahpasa Faculty of Medicine, Department of Clinical Microbiology, Istanbul,Turkey \\ 4 University of Health Sciences, Haydarpaşa Numune Training and Research Hospital, Clinic of Dermatology, Istanbul, Turkey \\ 5 University of Health Sciences, Haydarpaşa Numune Training and Research Hospital, Clinic of Pathology, Istanbul, Turkey
}

Keywords: Echthyma contagiosa, piperacillin tazobactam, contagious pustular dematitis, autoinoculation, nested polymerase chain reaction

Anahtar Kelimeler: Ektima kontagiyoza, piperasilin tazobaktam, konatgiyöz püstüler dermatit, otoinokülasyon, nested polimeraz zincir reaksiyonu

Dear Editor,

Orf is a zoonotic infection caused by a parapoxvirus that commonly infects small ruminants such as sheep and goats. The disease is also referred to as ecthyma contagiosa or contagious pustular dermatitis. It is transmitted to humans by direct contact with infected animals or their contaminated materials. The most important predisposing factor is the loss of epithelial barrier integrity. Humans who are in contact with infected animals, meat, and carcasses may be infected by direct inoculation through abrasions on the skin $^{[1,2]}$. Clusters of orf infection may be seen in Muslim populations after Eid al-Adha (the Islamic Feast of Sacrifice) due to increased animal slaughter activity ${ }^{[1,2]}$. In humans, the disease manifests mostly as an ulcerative solitary skin lesion, typically on the fingers, hands, or forearms ${ }^{[2]}$. However, atypical lesions and lesions in unusual locations such as the face, scalp, and genitalia have also been described ${ }^{[1,2]}$.
Orf is a self-limiting disease and usually resolves within 3-6 weeks. However, some cases may be complicated by secondary bacterial infection, lymphangitis, erysipelas, papulovesicular eruption, and erythema multiforme ${ }^{[3]}$. Herein, we report a case of orf with erythema multiforme and vesiculo-bullous lesions.

A 52-year-old woman was referred to our clinic with painful lesions on the fingers of her right hand. About 5 years earlier she had been performed right breast radical mastectomy with axillary lymph node excision and her chemotherapy protocol had already been completed before admission to our unit. She had history of contact with the head of a slaughtered sheep during the Eid al-Adha, 10 days before the appearance of the first lesion. She stated that two weeks later, a second lesion had developed on a skin burn wound on the same hand. Physical examination revealed an ulcerate lesion on the second finger and a papular lesion surrounded by hemorrhagic bullae 
with a target appearance on the third finger of the right hand (Figure 1). Small vesicles on an erythematous base were observed on her right forearm and medial surface of the upper arm (Figure 2), and erythema multiforme lesions were noted on her left thigh (Figure 3). No symptoms or abnormal physical findings suggesting rheumatologic disease was observed. Laboratory tests showed her white blood cell count was 5000/ $\mathrm{mm}^{3}$ and C-reactive protein level was $0.4 \mathrm{mg} / \mathrm{dl}$. The patient was hospitalized for severe pain and itching on the affected right arm. The vesicular lesions on the forearm progressed to vesiculo-bullous form accompanied by swelling and redness. A skin biopsy and microbiological tests from the lesions were performed. Citrobacter braakii and Enterobacter aerogenes were identified in the skin ulcer culture, and piperacillintazobactam was initiated. Histopathological examination findings of epidermal acanthosis, hyperkeratosis, intraepidermal vesicles, lymphocytes, macrophages, eosinophils, and plasma cells in the dermis were consistent with an orf infection. Viral DNA was extracted from a tissue biopsy using High Pure DNA extraction kit (ROCHE, Germany). A nested polymerase chain reaction (PCR) protocol was used for detection of parapoxvirus DNA in sample $\mathrm{e}^{[4]}$. The PCR products were purified by using EZ-10

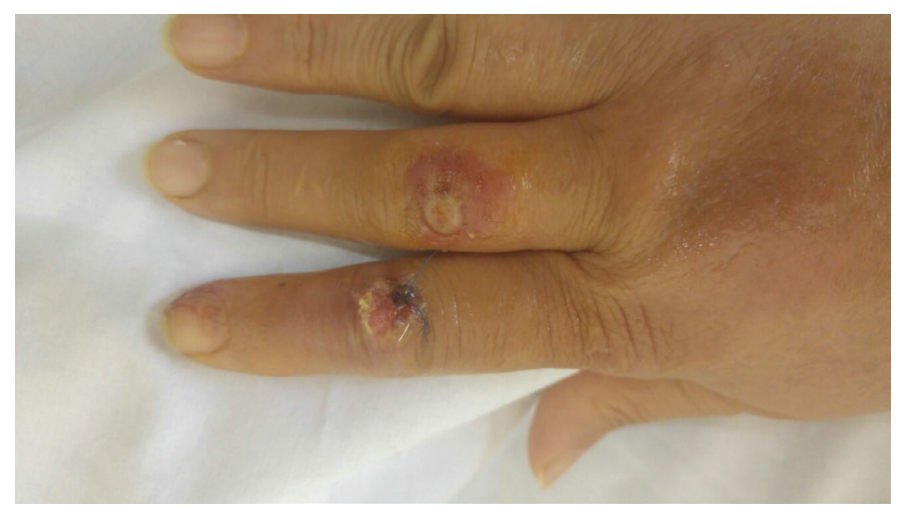

Figure 1. An ulcerate lesion on the second finger and a papular lesion surrounded by hemorrhagic bullae with a target appearance on the third finger

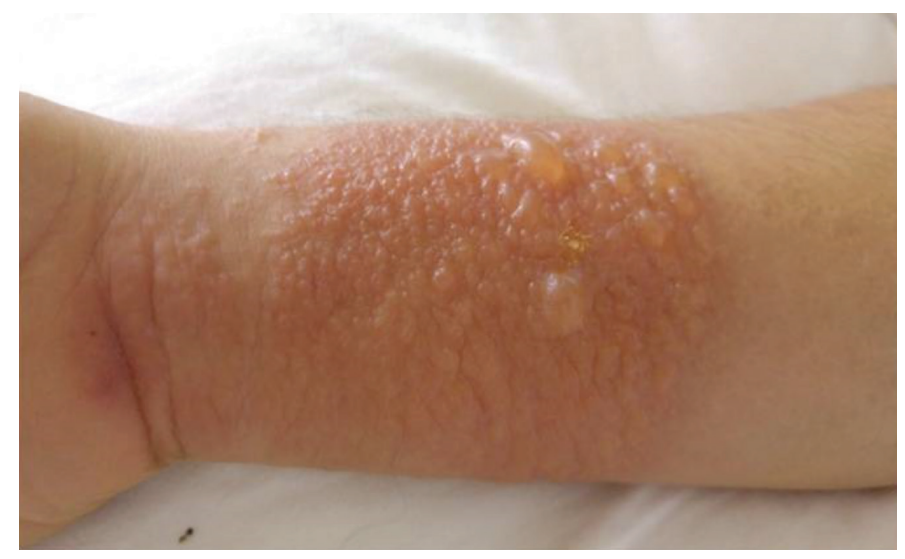

Figure 2. Small vesicles on an erythematous base on the right forearm and medial surface of the upper arm
Spin Column Gel Extraction kit (Bio Basic, Ontario, Canada) and sequenced bi-directionally on ABI-PRISM310 Genetic Analyzer using BigDye chemistry (Applied Biosystems, CA, USA). The PCR test for parapoxvirus was positive. The patient's lesions completely resolved within 20 days of hospital admission.

Although human cases of orf occur commonly as a result of occupational exposure to infected animals, they may also develop in a nonoccupational setting ${ }^{[1,2]}$. As in our case, household meat processing or animal slaughter for traditional ritual purposes may pose considerable risk.

Orf is a self-limiting disease and spontaneous resolution usually occurs in 3 to 6 weeks without complication. However, clinical manifestations may vary depending on patient-related factors $^{[1,2]}$.

Host immunity plays a major role in limiting the severity of orf. The clinical presentation of orf disease is variable in patients with T cell dysfunction. Atypical, giant, multiple, and recurrent lesions may be seen ${ }^{[1,5]}$. Although there was no apparent immunosuppression in our case, the patient had history of radical mastectomy. The upper extremity lesions were on the same side as the mastectomy. This might have resulted in an adverse effect on disease severity. Another remarkable point in this case is the occurrence of a secondary lesion due to autoinoculation of burned skin on a different finger. There are a few case reports of secondary lesions related to viral autoinoculation ${ }^{[6]}$. However,

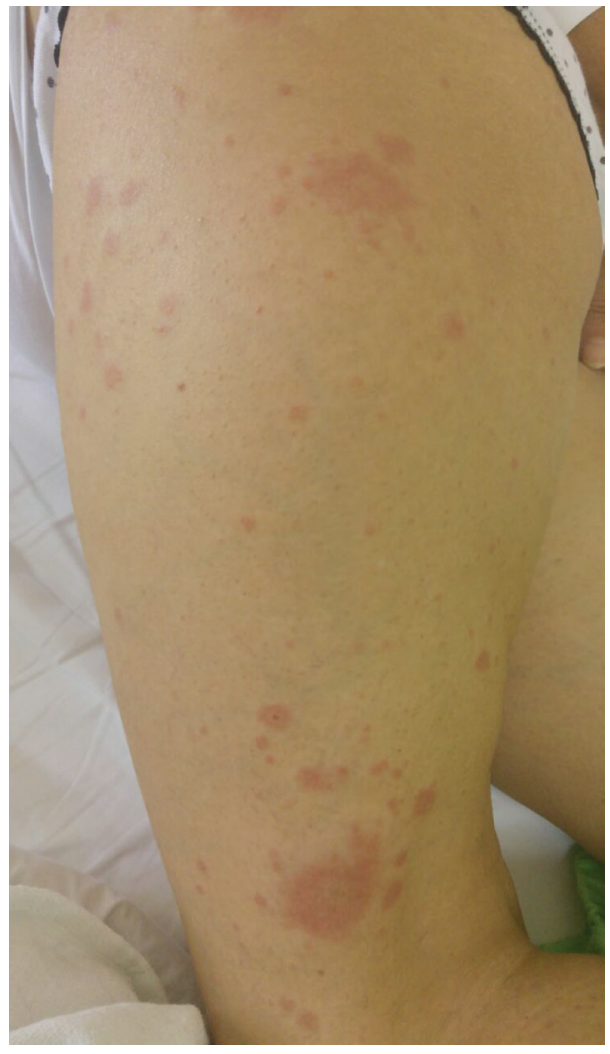

Figure 3. Erythema multiforme lesions on left thigh 
none of them were related to burn wounds. Burn wounds are prone to secondary infection with orf virus ${ }^{[7]}$.

Erythema multiforme is another uncommon manifestation of orf disease ${ }^{[3,8]}$. It is considered to be a type 4 hypersensitivity reaction to some infections, drugs, and vaccinations ${ }^{[9]}$. It is estimated that around $6.5 \%$ to $18 \%$ of orf cases are accompanied by erythema multiforme, which usually occurs 2-4 weeks after the appearance of orf lesions and resolves spontaneously within a few weeks ${ }^{[1,3]}$. Papulovesicular, bullous pemphigoid-like, and bullous pemphigoid eruptions have also been reported after orf infection, and may be associated with erythema multiforme, as in our patient ${ }^{[9]}$. In a previous study, orf-induced pemphigoid was attributed to virus mimicry of host proteins and alteration of basement membrane proteins by the virus ${ }^{[10]}$. In the study, orfinduced immunobullous disease was also regarded as a unique disease entity that is clinically and immunologically distinct from bullous pemphigoid, epidermolysis bullosa acquisita, and other known immunobullous conditions.

Despite its rarity, this case highlights the fact that orf disease should be included in the differential diagnosis of erythematous nodules and targetoid or crusted skin lesions, especially on the hands or $\operatorname{arms}^{[3]}$.

Public health officials should inform individuals handling animals for occupational purposes or religious practice about the potential risk of transmission of orf and other zoonotic infections, as well as protection measures against transmission. In addition, clinicians should be aware of orf and its secondary manifestations for proper case management. Further studies are needed to identify viral and individual risk factors for secondary manifestations of orf disease.

\section{Ethics}

Informed Consent: Informed consent was received from the presented case.

Peer-review: Externally and internally peer-reviewed.

\section{Authorship Contributions}

Surgical and Medical Practices: S.E., C.A.K., S.S., S.A., Analysis or Interpretation: S.E., C..A.K., S.Ş., M.A.K., K.M., P.G., Writing: S.E., Ç.A.K., S.Ş.

Conflict of Interest: No conflict of interest was declared by the authors.

Financial Disclosure: The authors declared that this study received no financial support.

\section{References}

1. Bergqvist $C$, Kurban $M$, Abbas 0 . Orf virus infection. Rev Med Virol. 2017;27(4).

2. Demiraslan $H$, Dinc G, Doganay M. An overview of Orf virus infection in humans and animals. Recent Pat Antiinfect Drug Discov. 2017;12:21-30.

3. Saçar H, Uyar B, Saçar T, Duran A. Investigation of the complications and incidences of orf disease during and after the Feast of the Sacrifice period. Dermatologica Sinica. 2015;33:191-5.

4. Abrahão JS, Lima LS, Assis FL, Alves PA, Silva-Fernandes AT, Cota MM, Ferreira VM, Campos RK, Mazur C, Lobato ZI, Trindade GS, Kroon EG. Nested multiplex PCR detection of Orthopoxvirus and Parapoxvirus directly from exanthematic clinical samples. Virol J 2009;6:140

5. Ran $\mathrm{M}$, Lee $\mathrm{M}$, Gong J, Lin Z, Li R. Oral acyclovir and intralesional interferon injections for treatment of giant pyogenic granuloma-like lesions in an immunocompromised patient with human orf. JAMA Dermatol. 2015:151:1032-4

6. Duchateau NC, Aerts 0 , Lambert J. Autoinoculation with orf virus (ecthyma contagiosum). Int J Dermatol. 2014;53:60-2.

7. Hsu $\mathrm{CH}$, Rokni $\mathrm{GR}$, Aghazadeh $\mathrm{N}$, Brinster $\mathrm{N}$, Li $\mathrm{Y}$, Muehlenbachs $\mathrm{A}$, Goldsmith CS, Zhao H, Petersen B, McCollum AM, Reynolds MG. Unique presentation of orf virus infection in a thermal-burn patient after receiving an autologous skin graft. J Infect Dis. 2016;214:1171-4.

8. Joseph RH, Haddad FA, Matthews AL, Maroufi A, Monroe B, Reynolds M. Erythema multiforme after orf virus infection: a report of two cases and literature review. Epidemiol Infect. 2015;143:385-90.

9. Lerch M, Mainetti C, Terziroli Beretta-Piccoli B, Harr T. Current perspectives on erythema multiforme. Clin Rev Allergy Immunol. 2018;54:177-84.

10. White KP, Zedek DC, White WL, Simpson EL, Hester E, Morrison L, Lazarova Z, Liu D, Scagliarini A, Kurtz SE, White CR Jr, Yancey KB, Blauvelt A. Orfinduced immunobullous disease: a distinct autoimmune blistering disorder. J Am Acad Dermatol. 2008;58:49-55. 